\title{
Perbandingan Kandungan Senyawa Kimia dan Aktivitas Antibakteri terhadap MRSA (Methicillin-resistant Staphylococcus aureus) Beberapa Minyak Atsiri Daun Salam (Syzygium polyanthum)
}

\section{Muhamad Salman Fareza, Esti Dyah Utami, Elesenda May Gita, Vintya Roosalinda Permatasari, Tryandika Telaumbanua, Nur Amalia Choironi*}

\author{
Jurusan Farmasi, Fakultas Ilmu-ilmu Kesehatan, Universitas Jenderal Soedirman, Jl. Dr. Soeparno, \\ Komplek Kampus Karangwangkal Purwokerto 53122 telp. (0281) 642840 \\ * Corresponding author \\ E-mail: n.a.choironi@gmail.com
}

DOI: 10.20961/alchemy.15.2.25736.302-314

Received 30 November 2018, Accepted 28 Maret 2019, Published 30 September 2019

\begin{abstract}
ABSTRAK
Daun Syzygium polyanthum secara tradisional telah digunakan untuk mengobati penyakit yang disebabkan oleh bakteri. Kandungan kimia dari minyak atsri dari suatu tanaman dipengaruhi oleh daerah asal tumbuhnya. Tujuan penelitian ini untuk mengetahui komponen minyak atsiri daun S. polyanthum dari Bekasi, Lembang, Purwokerto Baturaden dan Curup, serta aktivitas antibakterinya terhadap MRSA Minyak atsiri daun S. polyanthum diperoleh dengan metode destilasi uap. Kandungan komponen senyawa pada minyak atsiri dianalisis menggunakan GC-MS. Sifat antibakteri minyak atisri dievaluasi menggunakan metode difusi cakram pada rentang konsentrasi $12-100 \mathrm{ppm}$. Rendemen minyak atsiri daun S. polyanthum yang diperoleh dari Bekasi, Lembang, Purwokerto Baturaden dan Curup berturut-turut sebesar 0,03\%; 0,06\%; 0,072\%; 0,120\% dan $0,067 \%$. Hasil analisis GC-MS komponen minyak atsiri daun S. polyanthum dari berbagai daerah tersebut memperlihatkan senyawa aldehid dan terpenoid sebagai komponen utama. Minyak atsiri daun S. polyanthum dari Bekasi, Purwokerto, Baturaden dan Curup dapat memberikan daya hambat terhadap MRSA sebesar 9,2$15,3 \mathrm{~mm}$, sedangkan minyak atsiri dari Lembang tidak memberikan daya hambat. Minyak atsiri daun $S$. polyanthum daerah Baturaden memiliki aktivitas menghambat pertumbuhan bakteri MRSA lebih baik dibandingkan daerah lainnya yaitu $15,3 \mathrm{~mm}$ pada konsentrasi $100 \mathrm{ppm}$ dengan kategori intermediet. Penelitian mengenai perbandingan komponen kimia dan sifat antibakteri MRSA minyak atsiri daun S. polyanthum dari berbagai daerah ini baru pertama kali dilaporkan.
\end{abstract}

Kata kunci: Minyak atsiri,MRSA, Syzygium polyanthum.

\begin{abstract}
Comparison of Chemical Compounds in some Essential Oils of Salam Leaves (Syzygium polyanthum) and its Antibacterial Activity against MRSA (Methicillin-resistant Staphylococcus aureus). The Salam leaves of Syzygium polyanthum has been used traditionally to treat bacterial infections. The chemical constituents of essential oil from plant are affected by their growing place. The aims of this research are to know chemical constituents and antibacterial activity of Syzygium polyanthum essential oils from Bekasi, Lembang, Purwokerto, Baturaden, and Curup. Essential oils were obtained by steam distillation method. Chemical constituents of essential oils were analyzed with GC-MS. Evaluation of antibacterial activity was carried out by disk diffusion method with concentration used $12-100 \mathrm{ppm}$. The yield of the S. polyanthum essential oils from Bekasi, Lembang, Purwokerto, Baturaden and Curup were $0.03 \% ; 0.06 \% ; 0.072 \% ; 0.120 \%$ and $0.067 \%$, respectively. Aldehyde and terpenoid compounds were identified as mayor compound in $S$.
\end{abstract}


polyanthum essential oil. Essential oil from Bekasi, Purwokerto, Baturaden and Curup gave diameter zone of inhibition $9.2-15.3 \mathrm{~mm}$, while from essential oil Lembang did not provide inhibition. The essential oil of $S$. polyanthum leaves from Baturaden is more active against MRSA than the others, with diameter zone of inhibition $15.3 \mathrm{~mm}$ at $100 \mathrm{ppm}$ under intermediate category. Comparative study on the chemical compounds and antibacterial properties of the essential oil Salam leaves againts MRSA from different areas was first reported.

Keywords: Essential oils, MRSA, Syzygium polyanthum.

\section{PENDAHULUAN}

Resistensi antibiotik adalah salah satu masalah terbesar bagi kesehatan global. Salah satu patogen resisten adalah MRSA (Methicillin-resistant Staphylococcus aureus). MRSA merupakan patogen nosokomial yang dapat menyebabkan penyakit infeksi kulit dan jaringan lunak, seperti impetigo, endokarditis, bahkan sepsis (Erikawati et al., 2016; Grema, 2015). WHO (World Health Organization) melaporkan bahwa MRSA termasuk dalam prioritas tinggi patogen resisten yang harus diatasi dengan menggunakan agen antibakteri baru (WHO, 2017). Sumber pencarian agen antibakteri baru tersebut salah satunya dapat diperoleh dari suatu bahan alam seperti minyak atsiri. Bekka-Hadji et al. (2016) melaporkan bahwa minyak atsiri beberapa spesies tanaman famili Lamiaceae dari Algeria menunjukkan aktivitas antibakteri terhadap bakteri MRSA dengan nilai MIC (Minimum Inhibitory Concentration) 0,3-4,7 ppm dan diameter zona hambat sebesar 6,5-40,7 mm. Berdasarkan hal tersebut, maka minyak atsiri sangat berpotensi untuk diteliti dan dikembangkan sebagai agen antibakteri baru khususnya terhadap bakteri MRSA. Salah satu minyak atsiri yang memiliki potensi sebagai agen antibakteri MRSA adalah yang berasal dari daun Salam (Syzygium polyanthum).

S. polyanthum merupakan salah satu tanaman famili Myrtaceae yang secara empiris telah digunakan sebagai obat diare dan obat gatal topikal yang salah satu penyebabnya adalah bakteri S. aureus (Dalimartha, 2005). Berdasarkan hasil penelitian, ekstrak etanol dari daun $S$. polyanthum dapat menghambat bakteri S. aureus dengan nilai MIC 0,63 mg/mL dan zona hambat sebesar 9,33 \pm 0,52 mm (Ramli et al., 2017). Selain ekstrak, minyak atsiri dari daun S. polyanthum telah dilaporkan pula memiliki aktivitas antibakteri (Hamad et al., 2017). Adanya sifat farmakologis suatu bahan alam tentunya disebabkan adanya komponen kandungan kimia yang dimilikinya. Berdasarkan penelitian yang dilakukan Hamad et al., (2017), minyak atsiri daun S. polyanthum dari Purwokerto memiliki komponen mayor cis4-dekanal (43,489\%), 1-desil aldehida (19,752\%), $\alpha$-curcumene (2,271\%), sedangkan senyawa mayor minyak atsiri daun $S$. polyanthum yang berasal dari Malang dilaporkan mengandung senyawa cis-4-dekanal $(27,12 \%)$, oktanal $(11,98 \%)$, dan $\alpha$-pinen $(9,09 \%)$. 
Senyawa fenol, aldehid, dan terpenoid pada suatu minyak atsiri diduga yang berperan sebagai zat antimikroba (Bassolé dan Juliani, 2012; Saleem et al., 2010).

Sampai saat ini belum ada penelitian yang melaporkan tentang uji aktivitas minyak atsiri daun S. polyanthum terhadap bakteri MRSA, sedangkan apabila dilihat dari kandungan kimia dari minyak atsirinya maka tanaman tersebut dapat berpotensi sebagai antibakteri MRSA. Selain itu, analisis kandungan senyawa minyak atsiri dari S. polyanthum dari daerah Bekasi (Jawa Barat), Lembang (Jawa Barat), Baturaden (Jawa Tengah) dan Curup (Bengkulu) belum pernah dilaporkan. Adanya faktor perbedaan kondisi lingkungan sekitar tempat tumbuh tanaman, seperti suhu, iklim, tanah, dan curah hujan dapat berpengaruh terhadap jenis komponen maupun komposisi minyak atsiri suatu tanaman (Abdel-Hameed dan Bazaid, 2017; Toker et al., 2017). Berdasarkan latar belakang tersebut, maka dilakukan penelitian terkait pencarian agen antibakteri MRSA baru yang berasal dari minyak atsiri daun S. polyanthum. Selain itu, penelitian terkait analisa kandungan kimia minyak atsiri daun S. polyanthum dari berbagai daerah lain perlu dilakukan untuk mengetahui adanya pengaruh perbedaan komposisi kandungan kimia minyak atsiri daun $S$. polyanthum terhadap aktivitas antibakteri MRSA.

\section{METODE PENELITIAN}

Bahan yang digunakan dalam penelitian adalah daun S. polyanthum dari Bekasi (Jawa Barat), Lembang (Jawa Barat), Purwokerto (Jawa Tengah), Baturaden (Jawa Tengah) dan Curup (Bengkulu), isolat klinis bakteri MRSA, $\mathrm{Na}_{2} \mathrm{SO}_{4}$ anhidrat (EMSURE®), media Mueller-Hinton Agar (MHA) (Oxoid $\left.{ }^{\mathrm{TM}} \mathrm{CM} 0337\right), \mathrm{NaCl}$ 0,9\%, larutan standar Mc. Farland 0,5; dimetil sulfoksida (DMSO) (EMSURE®), akuades, kertas cakram (Oxoid ${ }^{\mathrm{TM}}$ ), vankomisin serta trimetoprim-sulfametoksazol.

Alat-alat yang digunakan dalam penelitian adalah seperangkat alat destilasi uap, seperangkat alat gelas, timbangan analitik (AND EK-1200i), GC-MS (Gas Chromatography-Mass Spectrometry) (Shimadzu QP 2010 Ultra), vortex (Fisher Scientific 231), kertas cakram (Oxoid ${ }^{\mathrm{TM}}$ ), autoklaf (All American 25x), dan inkubator (Memmert INB $500)$.

\section{Determinasi Tanaman}

Daun S. polyanthum diperoleh dari daerah Bekasi (Jawa Barat), Lembang (Jawa Barat), Purwokerto (Jawa Tengah), Baturaden (Jawa Tengah) dan Curup (Bengkulu) dideterminasi dengan membandingkan atau mencocokkan karakteristik morfologi tanaman 
S. polyanthum pada referensi Repertorium Botanices Systematicae. Determinasi tanaman dilakukan di Laboratorium Lingkungan Fakultas Biologi Universitas Jenderal Soedirman.

\section{Destilasi Minyak Atsiri}

Sebanyak $1 \mathrm{~kg}$ simplisia daun $S$. polyanthum diisolasi kandungan minyak atsirinya dengan metode destilasi uap (Sembiring et al., 2003). Proses destilasi dilakukan selama 8 jam dengan cara memasukkan daun Salam sebanyak $1 \mathrm{~kg}$ ke dalam labu destilasi dengan 2 L air. Distilat yang dihasilkan ditambahkan $\mathrm{Na}_{2} \mathrm{SO}_{4}$ anhidrat untuk memisahkan air dan minyak. Minyak atsiri yang diperoleh dihitung rendemennya terhadap bobot semula.

\section{Uji Aktivitas Antibakteri MRSA}

Uji aktivitas antibakteri dilakukan dengan mengacu pada Coyle (2005) dan EUCAST (2017). Semua alat tahan panas, medium, dan bahan yang akan digunakan dicuci bersih, dikeringkan, dan dibungkus dengan plastik/alumunium foil. Selanjutnya sterilisasi dilakukan menggunakan autoklaf pada suhu $121^{\circ} \mathrm{C}$ dan tekanan 1 atm selama 15 menit. Uji aktivitas antibakteri dilakukan secara in vitro menggunakan metode difusi cakram (uji Kirby-Bauer). Menurut Rios dan Recio (2005), suatu bahan alam selain isolat murni dapat dikatakan memiliki aktivitas antibakteri bila memiliki konsentrasi dibawah 100 ppm. Maka pada penelitian ini konsentrasi minyak atsiri yang digunakan adalah 12, 25, 50, dan 100 ppm dengan pelarut DMSO 100\% (v/v). Koloni bakteri MRSA, dengan usia tidak lebih dari 18-24

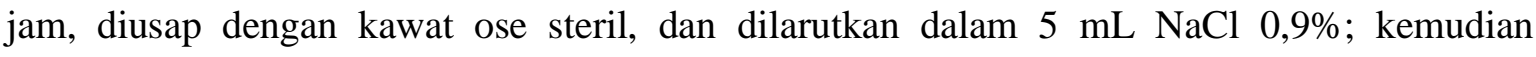
dihomogenkan dengan vortex lalu disesuaikan dengan standar turbiditas 0,5 Mc. Farland selama 15 menit. Penanaman MRSA dilakukan dengan cara mencelupkan cotton swab ke dalam suspensi cairan dan dioleskan di atas permukaan medium MHA secara merata. Kertas cakram $(\phi 6 \mathrm{~mm})$ direndam dalam setiap konsentrasi larutan minyak atsiri dan dalam pelarut DMSO selama 1 menit, kemudian diletakkan di permukaan media agar dengan pinset setelah sekitar 15 menit proses inokulasi. Cakram yang hanya direndam pelarut DMSO digunakan sebagai kontrol pelarut atau kontrol negatif, sedangkan cakram vankomisin $(30 \mu \mathrm{g})$ dan kotrimoksazol $(25 \mu \mathrm{g})$ sebagai kontrol positif. Uji difusi dilakukan dengan replikasi 3 kali. Kultur diinkubasi pada suhu $37^{\circ} \mathrm{C}$ selama 24 jam. Nilai zona hambat diperoleh dengan cara pengamatan pada lempeng agar dengan cara mengukur diameter daerah bening di sekitar cakram.

\section{Analisis Senyawa Minyak Atsiri Dengan GC-MS}

Minyak atsiri dari berbagai daerah dianalisa komponennya menggunakan GC-MS (Shimadzu QP 2010 Ultra). Minyak atsiri diinjeksikan sebanyak 0,2 $\mu \mathrm{L}$ ke dalam kolom 
RTX®-5-MS (difenil dimetil polisiloksan), panjang $30 \mathrm{~m}$, diameter 0,25 mm, suhu kolom $60{ }^{\circ} \mathrm{C}-270{ }^{\circ} \mathrm{C}$ (kenaikan $8{ }^{\circ} \mathrm{C} /$ menit), suhu injektor $280{ }^{\circ} \mathrm{C}$, suhu detektor $250{ }^{\circ} \mathrm{C}$, gas pembawa helium $(\mathrm{He})$, jenis pengion EI (Electron Impact), dan energi ionisasi $0,8 \mathrm{kV}$. Komponen minyak atsiri diidentifikasi berdasarkan waktu retensi dan pola fragmentasi. Pola spektrum dibandingkan dengan database Wiley 7 kemudian dipilih dan diidentifikasi puncak komponen yang memiliki similarity index $(\mathrm{SI}) \geq 90 \%$.

\section{HASIL DAN PEMBAHASAN}

Hasil rendemen minyak atsiri menunjukkan adanya perbedaan pada tiap daerah yang tertera pada Tabel 1. Berdasarkan hasil tersebut diperoleh bahwa minyak atsiri $S$. polyanthum dari Baturaden memiliki rendemen lebih tinggi $(0,120 \%)$ dibandingkan daerah lainnya. Hasil minyak atsiri S. polyanthum dari Purwokerto memiliki rendemen lebih rendah dibandingkan penelitian sebelumnya yang dilakukan oleh Hamad et al. (2017) yaitu 0,075\%. Namun, kelima minyak atsiri tersebut rendemennya lebih tinggi jika dibandingkan dengan minyak atsiri daun S. polyanthum yang berasal dari Sukabumi $(0,023 \%)$ dan Bogor $(0,018 \%)$ (Sembiring et al., 2015).

Tabel 1. Rendemen minyak atsiri daun S. polyanthum dari berbagai daerah.

\begin{tabular}{|c|c|}
\hline $\begin{array}{c}\text { Tempat tumbuh daun } S \text {. } \\
\text { polyanthum }\end{array}$ & Rendemen minyak atsiri (\%) \\
\hline Bekasi & 0,030 \\
\hline Lembang & 0,060 \\
\hline Purwokerto & 0,072 \\
\hline Baturaden & 0,120 \\
\hline Curup & 0,067 \\
\hline
\end{tabular}

Total kandungan minyak atsiri tanaman umumnya sangat rendah dan jarang melebihi 1\% (Aleksic dan Knezevic, 2014). Salah satu faktor yang mempengaruhi nilai rendemen tanaman adalah suhu. Suhu lingkungan yang rendah (rata-rata $<24^{\circ} \mathrm{C}$ ) akan mengurangi penguapan komponen minyak atsiri sehingga rendemen minyak atsiri yang diperoleh lebih tinggi. Suhu tempat tumbuh yang tinggi dapat mempengaruhi struktur kelenjar minyak tanaman dan sel epitel tanaman menjadi sensitif sehingga memicu destruksi membran tanaman yang dapat mengakibatkan permeabilitas tanaman menjadi meningkat (Mirhosseini et al., 2015). Berdasarkan hasil penelitian yang dilakukan, rendemen minyak atsiri yang diperoleh lebih tinggi pada daerah dataran rendah (Purwokerto dengan ketinggian $100 \mathrm{~m}$ dpl) daripada daerah dataran tinggi (Curup dengan ketinggian $500 \mathrm{~m} \mathrm{dpl}$ ) (Pemkab 
Banyumas, 2010; Pokja Rejang Lebong, 2012). Hasil penelitian ini berbanding terbalik dengan penelitian Sembiring et al (2003) yang memperoleh rendemen lebih tinggi pada daerah dataran tinggi (Sukabumi dengan ketinggian $450 \mathrm{~m}$ dpl) dibandingkan dataran rendah (Bogor dengan ketinggian $225 \mathrm{~m} \mathrm{dpl}$ ). Hal tersebut menunjukkan bahwa ketinggian tidak menjadi satu-satunya parameter hasil tinggi atau rendahnya rendemen minyak, sehingga perlu diperhatikan faktor-faktor lain, seperti iklim, tanah, atau curah hujan.

Berdasarkan data kromatogram hasil analisis dengan GC-MS menunjukkan adanya 29 senyawa pada minyak atsiri dari Bekasi, 55 senyawa pada minyak atsiri dari Lembang, 39 puncak senyawa pada minyak atsiri dari Purwokerto, 37 puncak senyawa pada minyak atsiri dari Baturaden dan 33 senyawa pada minyak atsiri dari Curup. Hasil tersebut berbeda dengan penelitian yang dilakukan oleh Hamad et al., (2017) yang memperoleh 27 senyawa pada minyak atsiri dari Malang. Jumlah senyawa minyak atsiri daun S. polyanthum dari Lembang lebih banyak dibandingkan senyawa minyak atsiri dari daerah lain sehingga warna kuning minyak atsiri dari Lembang lebih gelap dibandingkan daerah lainnya. Hal ini didukung oleh penelitian Negoro (2007) yang melaporkan warna minyak atsiri daun sirih, dengan senyawa sejumlah 64, lebih gelap dibandingkan warna minyak atsiri daun sirih, dengan senyawa sejumlah 56.

Berdasarkan data pada Tabel 2, minyak atsiri daun S. polyanthum dari Bekasi, Lembang, Purwokerto, Baturaden dan Curup memiliki 6 senyawa yang sama, yaitu $n$ heptanal, $n$-nonanal, cis-4-desenal, $n$-dekanal, 2-undekanon, dan nerolidol. Nerolidol adalah senyawa golongan seskuiterpenoid yang memberikan aroma khas minyak atsiri daun $S$. polyanthum (Sembiring et al., 2003). Senyawa lainnya merupakan senyawa khas yang hanya dimiliki masing-masing minyak atsiri daun S. polyanthum dari Bekasi, Lembang, Purwokerto, Baturaden maupun Curup. Beberapa senyawa yang hanya terdapat dalam minyak atsiri dari Bekasi, yaitu asam oktanoat, $\alpha$-panasinsen, $\alpha$-fensil asetat dan $\alpha$-terpinenil asetat. Beberapa senyawa yang hanya terdapat dalam minyak atsiri dari Lembang, yaitu asam trans-geranil aseton, $\alpha$-humulen dan farnesol isomer B. Beberapa senyawa yang hanya terdapat dalam minyak atsiri dari Baturaden, yaitu valensen, $\alpha$-kurkumen, $\alpha$-selinen, asam fosfonat, geosmin, $\beta$-selinen, humulen oksida, farnesil asetat dan etil linoleat. Beberapa senyawa yang hanya terdapat dalam minyak atsiri dari Curup, yaitu cis-jasmon, asam heksadekanoat dan isofitol. Adapun minyak atsiri dari Baturaden tidak terdapat komponen khas. Senyawa minyak atsiri daun S. polyanthum dari tempat tumbuh yang berbeda memiliki perbedaan juga pada jumlah dan jenisnya. Faktor seperti konsentrasi nutrien dalam tanah 
atau kondisi tanah, intensitas cahaya, suhu, cuaca, dan kelembaban mempengaruhi fisiologis tanaman serta jalur biosintesis tanaman sehingga tanaman dengan spesies yang sama dapat memiliki tipe komponen yang berbeda (Aleksic dan Knezevic, 2014).

Tabel 2. Perkiraan kandungan senyawa pada minyak atsiri daun S. polyanthum

\begin{tabular}{|c|c|c|c|c|c|}
\hline \multirow{2}{*}{ Komponen senyawa } & \multicolumn{5}{|c|}{ Luas area $(\%)$} \\
\hline & Bekasi & Lembang & Purwokerto & Baturaden & Curup \\
\hline Heksana & - & - & 2,63 & - & - \\
\hline Metilsiklopentana & 0,20 & - & - & - & - \\
\hline$n$-Heksanal & - & - & - & 0,11 & - \\
\hline 2-propil-1-heptanol & - & - & 0,11 & - & - \\
\hline 2-butil-1-oktanol & - & - & - & 0,29 & - \\
\hline$n$-Heptanal & 0,37 & 0,13 & 0,09 & 0,26 & 0,36 \\
\hline$\alpha$-Pinen & 0,15 & - & - & 0,08 & - \\
\hline n-Oktanal & 33,64 & 13,60 & - & 15,82 & 39,75 \\
\hline 1,8-Sineol & 0,29 & 0,21 & - & 0,13 & - \\
\hline$n$-Nonanal & 0,61 & 0,24 & 0,63 & 0,51 & 0,60 \\
\hline Asam oktanoat & 0,55 & - & - & - & - \\
\hline cis-4-Dekenal & 25,74 & 10,97 & 39,15 & 30,58 & 19,00 \\
\hline$n$-Dekanal & 15,15 & 8,93 & 25,59 & 15,37 & 19,09 \\
\hline 2-Undesenil asetat & - & - & 0,13 & - & - \\
\hline$\alpha$-Fensil asetat & 0,16 & - & - & - & - \\
\hline 2-Undekanon & 0,27 & 0,21 & 0,19 & 0,10 & 0,33 \\
\hline$\alpha$-Terpinenil asetat & 0,14 & - & - & - & - \\
\hline$\alpha$-Kopaen & - & 0,34 & 0,66 & 0,91 & - \\
\hline Asam dekanoat & - & 0,81 & 0,26 & - & 5,25 \\
\hline $13-$ & - & - & 0,08 & - & - \\
\hline Oksabisiklo[10.1.0]tridekana & & & & & \\
\hline cis-Jasmone & - & - & - & - & 0,22 \\
\hline Dodekanal & - & - & 0,21 & - & 0,16 \\
\hline$\alpha-$ Ionon & - & 0,23 & - & - & 0,12 \\
\hline $\begin{array}{l}\text { 2,4-Pentandion,3-(1-metil-2- } \\
\text { propenil)- }\end{array}$ & - & - & 0,006 & - & - \\
\hline trans- Geranilaseton & - & 0,20 & - & - & - \\
\hline$\alpha$-Humulen & - & 0,21 & - & - & - \\
\hline Valensen & - & - & 0,09 & - & - \\
\hline$\alpha$-Kurkumen & - & - & 0,07 & - & - \\
\hline 2-Oksa-trisiklo[4.3.1.0 & - & - & 0,22 & - & - \\
\hline 3,8]dekana & & & & & \\
\hline$\beta$ - Selinen & - & - & 0,45 & - & - \\
\hline Humulen oksida & - & - & 0,15 & - & - \\
\hline $\begin{array}{l}\text { 6-Hidroksimetil-1,4,4- } \\
\text { trimetil-bisiklo(3.1.0)heksan- } \\
\text { 2-ol }\end{array}$ & - & - & 0,48 & - & - \\
\hline $\begin{array}{l}\text { Bisiklo[4.4.0]dek-1-en,1- } \\
\text { isopropil-5- metil-9-metilen }\end{array}$ & - & - & 0,23 & - & - \\
\hline
\end{tabular}


Tabel 2. Perkiraan kandungan senyawa ..... (Lanjutan)

\begin{tabular}{lccccc}
\hline \multirow{2}{*}{ Komponen senyawa } & \multicolumn{5}{c}{ Luas area (\%) } \\
\cline { 2 - 6 } & Bekasi & Lembang & Purwokerto & Baturaden & Curup \\
\hline Farnesol Isomer B & - & 2,11 & - & - & - \\
$\alpha-K a d i n o l$ & - & - & 0,27 & - & - \\
6,10,14- Trimetil-2- & 0,19 & - & - & - & 1,45 \\
Pentadekanon & - & - & - & - & 0,53 \\
Isofitol & - & - & 0,60 & 0,78 & - \\
Farnesil asetat & - & - & 0,57 & - & - \\
Siklopentana, 1,2-dipropil- & - & - & 0,27 & - & - \\
2-N-butil-3-n- & - & - & - & - & 0,29 \\
heksildekahidronaftalen & - & 0,74 & - & - & 3,98 \\
Asam heksadekanoat & - & - & 1,79 & - & - \\
Fitol & - & - & 0,14 & - & - \\
6-Tridesen-6-al & - & - & 1,08 & - & - \\
Etil linoleate & & & & & \\
2,5-Furandion - & &
\end{tabular}

Minyak atsiri umumnya tersusun dari senyawa terpenoid dan non-terpenoid yang mudah menguap. Golongan terpenoid merupakan golongan yang paling banyak terdapat dalam minyak atsiri, seperti monoterpenoid dan seskuiterpenoid. Golongan terpenoid dapat dibagi menjadi 2, yaitu terpenoid hidrokarbon dan terpenoid teroksigenasi. Terpenoid hidrokarbon dapat berbentuk asiklik, siklik, atau aromatik. Terpenoid teroksigenasi merupakan turunan terpenoid yang memiliki gugus fungsi, seperti aldehida, alkohol, ester, keton, eter, peroksida, dan fenol. Golongan non-terpenoid, seperti fenilpropanoid, juga sering ditemukan dalam minyak atsiri dalam bentuk fenol atau fenol eter. Senyawa hidrokarbon sederhana, seperti alkana, alkena, dan benzenoid juga termasuk non-terpenoid yang terdapat dalam minyak atsiri (Tongnuanchan dan Benjakul, 2014; Zuzarte dan Salgueiro, 2015). Persentase komponen minyak atsiri daun S. polyanthum pada penelitian ini didominasi oleh golongan aldehid kemudian terpenoid (Tabel 3).

Tabel 3. Presentase golongan senyawa pada minyak atsiri daun S. polyanthum

\begin{tabular}{lrrrrr}
\hline \multicolumn{1}{c}{ Golongan senyawa } & \multicolumn{5}{c}{ Kandungan total (\%) } \\
& Bekasi & Lembang & Purwokerto & Baturaden & Curup \\
\hline Aldehida & 75,51 & 33,87 & 67,46 & 66,88 & 79,54 \\
Terpenoid & 4,8 & 7,59 & 5,18 & 6,45 & 7,90 \\
Asam lemak & 0,55 & 0,81 & 0,53 & - & 5,54 \\
Keton & 0,46 & 0,41 & 1,27 & 0,10 & 1,65 \\
Ester & - & - & 0,14 & - & - \\
Alkohol & - & - & 0,24 & 0,29 & - \\
Alkana & 0,2 & - & 3,28 & - & - \\
\hline
\end{tabular}


Berbagai minyak atsiri daun $S$. polyanthum tersebut diuji aktivitas antibakterinya terhadap isolat klinis bakteri MRSA dengan metode difusi cakram (Gambar 1). Hasil uji menunjukkan terbentuknya daerah bening di sekitar cakram yang direndam dalam semua konsentrasi larutan minyak atsiri daun S. polyanthum dari Bekasi, Purwokerto, Baturaden dan Curup. Daerah bening juga terbentuk di sekitar cakram antibiotik sebagai kontrol positif, yaitu vankomisin dan kotrimoksazol. Daerah bening tidak terbentuk di sekitar cakram yang direndam dalam semua konsentrasi larutan minyak atsiri daun S. polyanthum dari Lembang dan juga di sekitar cakram yang direndam dalam pelarut sebagai kontrol negatif, yaitu DMSO (Gambar 1). Nilai diameter daerah bening atau zona hambat tertera pada Tabel 4.

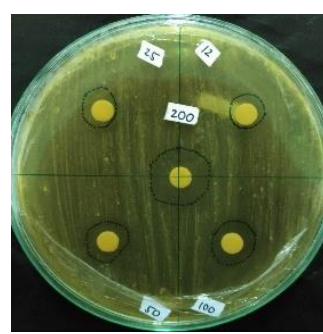

(a)

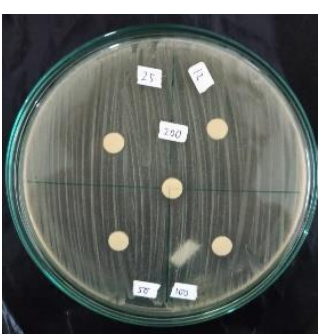

(b)

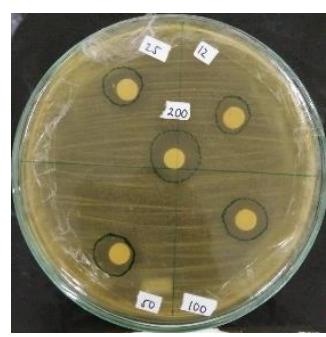

(c)

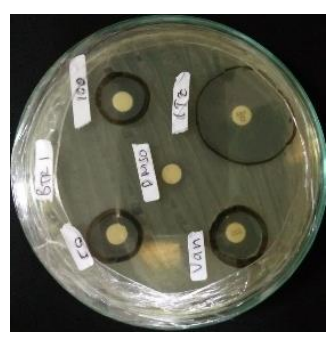

(d)

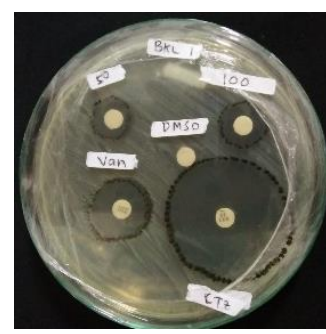

(e)

Gambar 1. Diameter zona hambat Syzygium polyanthum dari (a) Bekasi; (b) Lembang; (c) Purwokerto; (d) Baturaden: (e) Curup

Tabel 4. Diameter zona hambat minyak atsiri daun S. polyanthum terhadap MRSA

\begin{tabular}{cccccc}
\hline Konsentrasi & \multicolumn{5}{c}{ Diameter zona hambat $(\mathrm{mm})$} \\
\cline { 2 - 5 }$(\mathrm{ppm})$ & Bekasi & Lembang & Purwokerto & Baturaden & Curup \\
\hline 12 & 9,2 & 0 & 10,4 & 10,8 & 0 \\
25 & 10,5 & 0 & 11,1 & 11,8 & 9,8 \\
50 & 11,9 & 0 & 13,0 & 14,8 & 12,2 \\
100 & 13,2 & 0 & 14,6 & 15,3 & 13,6 \\
DMSO & & 0 & \\
Vankomisin & & 19,8 & \\
Kotrimoksazol & & 32 & \\
\hline
\end{tabular}


Berdasarkan Tabel 4. minyak atsiri daun S. polyanthum daerah Bekasi, Purwokerto, Baturaden dan Curup dapat menghambat pertumbuhan bakteri MRSA dengan nilai diameter zona hambat yang meningkat seiring dengan peningkatan konsentrasi larutan minyak atsiri. Berdasarkan CLSI (Clinical and Laboratory Standards Institute) (2017), nilai diameter zona hambat dari uji in vitro aktivitas antibakteri dapat diinterpretasikan ke dalam kategori susceptible (diameter zona hambat $\geq 20 \mathrm{~mm}$ ), intermediate (diameter zona hambat 15-19 $\mathrm{mm}$ ), dan resistant (diameter zona hambat $\leq 14 \mathrm{~mm}$ ). Minyak atsiri daun $S$. polyanthum dari Bekasi, Purwokerto dan Curup pada konsentrasi 100 ppm, termasuk kategori resistant dalam menghambat bakteri MRSA, sedangkan minyak atsiri dari Baturaden termasuk kategori intermediate. Minyak atsiri daun S. polyanthum dari Lembang termasuk kategori tidak aktif dengan tidak menunjukkan daerah zona hambat pada sekitar cakram uji.

Minyak atsiri yang mengandung aldehid, fenol sebagai senyawa mayor menunjukkan aktivitas antibakteri tertinggi, diikuti oleh minyak atsiri yang mengandung terpenoid alkohol (Dhifi et al., 2016). Hal tersebut juga telah dilaporkan dari hasil penelitian oleh Faleiro dan Miguel (2013) bahwa minyak atsiri dari berbagai tanaman yang memiliki senyawa mayor golongan aldehid, seperti senyawa dekanal (18\%), dodekanal $(4,1 \%)$, dan sitronelal $(3,9 \%)$, mampu menghambat bakteri MRSA, VRSA (Vancomycin-resistant Staphylococcus aureus) dan E. coli. Pada penelitian ini diperoleh komponen terbesar dalam minyak atsiri daun $S$. polyanthum adalah golongan aldehid dengan persentase 75,51\% (Bekasi), 33,87\% (Lembang), 67,46\% (Purwokerto), 66,88\% (Baturaden) dan 79,54\% (Curup). Hal ini juga membuktikan bahwa pada minyak atsiri asal Lembang yang memiliki kandungan aldehid paling rendah tidak memiliki aktivitas antibakteri MRSA (Tabel 3).

Senyawa lain yang diduga dapat memberikan aktivitas penghambatan terhadap bakteri adalah $\alpha$-pinen dan 1,8-sineol. Menurut Soković et al., (2010), senyawa $\alpha$-pinen dan 1,8-sineol merupakan senyawa dalam minyak atsiri yang juga memiliki potensi antibakteri. Minyak atsiri daun S. polyanthum dari Bekasi dan Baturaden mengandung senyawa $\alpha$-pinen, sedangkan dalam minyak atsiri daun $S$. polyanthum dari Lembang, Purwokerto dan Curup tidak teridentifikasi adanya $\alpha$-Pinen. Minyak atsiri daun $S$. polyanthum dari Bekasi, Lembang dan Baturaden mengandung senyawa 1,8-sineol, sedangkan dalam minyak atsiri daun S. polyanthum dari Purwokerto dan Curup tidak teridentifikasi adanya 1,8-Sineol.

Ekstrak daun S. aromaticum memiliki efek bakterisidal terhadap bakteri MRSA pada konsentrasi $0,256 \mathrm{mg} / \mathrm{mL}$ dan S. antisepticum pada konsentrasi 0,125 mg/mL. Eugenol dan $\beta$-kariofilen merupakan komponen senyawa pada $S$. aromaticum yang diduga berperan 
memberikan aktivitas antibakteri dengan cara menginduksi kerusakan dinding sel (Mandal et al., 2011; Yuan dan Yuk, 2018).

\section{KESIMPULAN}

Berdasarkan penelitian yang dilakukan, minyak atsiri S. polyanthum dari lima daerah yang berbeda memiliki kandungan utama senyawa aldehid dan terpenoid. Apabila dibandingkan daerah lainnya, minyak atsiri yang berasal dari daerah Curup memiliki kandungan komponen kimia aldehid (79,54\%) dan terpenoid (7,90\%) terbesar. Minyak atsiri asal Bekasi, Purwokerto, dan Curup menunjukkan sifat antibakteri resisten terhadap MRSA pada semua konsentrasi yang diujikan. Hanya minyak atsiri yang berasal dari Baturaden pada konsentrasi 100 ppm yang memperlihatkan sifat antibakteri intermediet terhadap MRSA. Adanya kandungan senyawa aldehid dan terpenoid pada minyak atsiri tersebut diduga yang berperan dalam memberikan aktivitas antibakterinya.

\section{UCAPAN TERIMAKASIH}

Ucapan terimakasih kepada penyandang dana penelitian, BLU UNSOED pada skim penelitian Riset Dosen Pemula dengan no SK Kept.2352/UN23.14/PN.01.00/2018.

\section{DAFTAR PUSTAKA}

Abdel-Hameed, E.S. dan Bazaid S.A., 2017. Chemical Composition of Essential Oil from Leaves of Schinus molle L. Growing in Taif, KSA. Journal of Essential Oil Bearing Plants 20 (1), 45-58. doi: 10.1080/0972060X.2017.1294999.

Aleksic, V. dan Knezevic P., 2014. Antimicrobial and Antioxidative Activity of Extracts and Essential Oils of Myrtus communis L. Medicinal Extracts in Microbiology 169 (4), 240-254. doi: 10.1016/j.micres.2013.10.003.

Bassolé, S.I.H.N. dan Juliani H.R., 2012. Essential Oils in Combination and Their Antimicrobial Properties. Molecules 17 (4), 3989-4006. doi: 10.3390/molecules17043989.

Bekka-Hadji, F., Bombarda I., dan Touati A., 2016. Antibacterial Activity Against Methicillin-Resistant Staphylococcus aureus of Five Essential Oils from Algerian Medicinal Plants (Lamiaceae). Journal of Essential Oil Research 28 (6), 518-527. doi: 10.1080/10412905.2016.1161564.

CLSI (Clinical and Laboratory Standards Institute), 2017. Performance Standards for Antimicrobial Susceptibility Testing. 27th Ed. CLSI Supplement M100, Wayne PA, USA 37 (1), 4.

Coyle, M.B, 2005. Manual of Antimicrobial Susceptibility Testing. American Society for Microbiology, USA. 
Dalimartha, S, 2005. Tanaman Obat di Lingkungan Sekitar. Puspa Swara, Jakarta 45.

Dhifi, W., Bellili, S., Jazi, S., Bahloul, N., Mnif, W., 2016. Essential Oils’ Chemical Characterization and Investigation of Some Biological Activities: A Critical Review. Medicines (Basel) 3 (4), 1-16. doi: 10.3390/medicines3040025.

Erikawati, D., Santosaningsih D., dan Santoso S., 2016. Tingginya Prevalensi MRSA pada Isolat Klinik Periode 2010- 2014 di RSUD Dr. Saiful Anwar Malang, Indonesia. Jurnal Kedokteran Brawijaya 29 (2), 149-56. doi: 10.21776/ub.jkb.2016.029.02.9.

European Committee for Antimicrobial Susceptibility Testing (EUCAST), 2017. EUCAST Disk Diffusion Method for Antimicrobial Susceptibility Testing Version 6.0. European Society of Clinical Microbiology and Infection, 1-26.

Faleiro, M.L., dan Miguel, M.G., 2013. Chapter 6 - Use of Essential Oils and Their Components against Multidrug-Resistant Bacteria. Academic Press, San Diego, 6594.

Grema, H.A., 2015. Methicillin Resistant Staphylococcus aureus (MRSA): A Review. Advances in Animal and Veterinary Sciences 3 (2), 79-98. doi: 10.1016/j.jgar.2016.07.010.

Hamad, A., Mahardika M.G.P., Yuliani I., dan Hartanti D., 2017. Chemical Constituents and Antimicrobial Activities of Essential Oils of Syzygium polyanthum and Syzygium aromaticum. Rasayan Journal Chemistry $10 \quad$ (2), 564-569. doi: 10.7324/RJC.2017.1021693.

Mandal S., Mandal MD., Saha K., Pal NK., 2011. In Vitro Antibacterial Activity of Three Indian Spices Against Methicillin-Resistant Staphylococcus aureus. Oman Medical Journal 26 (5), 319-323. doi: 10.5001/omj.2011.80.

Mirhosseini, F., Rahimmalek, M., Pirbalouti, A.G., Taghipoor, M., 2015. Effect of Different Drying Treatments on Essential Oil Yield, Composition and Color Characteristics of Kelussia odoratissima Mozaff. Journal of Essential Oil Research 27 (3), 204-211. doi: 10.1080/10412905.2015.1015691.

Negoro, A.M., 2007. Penentuan Metode Terbaik Proses Penyulingan Minyak Atsiri Daun Sirih (piper betle LINN.) antara Penyulingan dengan Air dan Penyulingan dengan Air dan Uap. Skripsi, Universitas Sanata Dharma, Yogyakarta.

Pemkab Banyumas, 2010. Perda No 11 tentang Rencana Pembangunan Jangka Menengah Kabupaten Banyumas Tahun 2008-2013. Banyumas.

Pokja Rejang Lebong, 2012. Program Percepatan Pembangunan Sanitasi. Rejang Lebong, Bengkulu.

Ramli, S., Radu, S., Shaari, K., dan Rukayadi, Y., 2017. Antibacterial Activity of Ethanolic Extract of Syzygium polyanthum L. (Salam) Leaves Against Foodborne Pathogens and Application as Food Sanitizer. BioMed Research International 1-3. doi: $10.1155 / 2017 / 9024246$.

Rios, J.L., Recio, M.C., 2005. Medicinal Plants and Antimicrobial Activity. Journal of Ethnopharmacology 100: 80-84. doi: 10.1016/j.jep.2005.04.025.

Saleem, M., Nazir, M., Ali, M.S., Hussain, H., Lee, Y.S., Riaz, N., and Jabbar, A., 2010. Antimicrobial natural products: an update on future antibiotic drug candidates. Natural Product Reports. 27, 238-254. 
Sembiring, B.S., Winarti C., dan Baringbing B., 2003. Identifikasi Komponen Kimia Minyak Daun Salam (Eugenia polyantha) dari Sukabumi dan Bogor. Buletin Penelitian Tanaman Rempah dan Obat 14 (2), 9-16. doi: 10.21082/bullittro.v14n2.2003.\%25p.

Soković, M., Glamočlija, J., Marin, P.D., Brkić, D., van Griensven, L.J.L.D., 2010. Antibacterial Effects of The Essential Oils of Commonly Consumed Medicinal Herbs Using an In Vitro Model. Molecules (Basel, Switzerland) 15 (11), 7532-7546. doi: 10.3390/molecules15117532.

Toker, R., Muharrem G., dan Haluk T., 2017. Effects of Distillation Times on Essential Oil Compositions of Origanum minutiflorum O. Schwarz Et. and P.H. Davis. Journal of Essential Oil Research 29 (4), 330-335. doi: 10.1080/10412905.2016.1276026.

Tongnuanchan P., Benjakul S., 2014. Essential Oils: Extraction, Bioactivities, and Their Uses for Food Preservation. Journal of Food Science 79 (7), R1231-R1249. DOI: 10.1111/1750-3841.12492.

WHO, 2017. WHO Publishes List of Bacteria for Which New Antibiotics Are Urgently Needed. http://www.who.int (diakses 27 Oktober 2018).

Yuan W., Yuk HG., 2018. Antimicrobial Efficacy of Syzygium antisepticum Plant Extract Against Staphylococcus aureus and Methicillin-Resistant $S$. aureus and Its Application Potential with Cooked Chicken. Food Microbiol (72), 176-184. doi: 10.1016/j.fm.2017.12.002.

Zuzarte, M., Salgueiro, L., 2015. Chapter 2 - Essential Oils Chemistry, dalam de Sousa D.P., Bioactive Essential Oils and Cancer. Springer International Publishing, Switzerland, 19-61. 